\title{
Tingkat Efikasi Diri Performa Akademik Mahasiswa Ditinjau Dari Perspektif Dimensi Bandura
}

\author{
Siti Fatimah ${ }^{1}$, Ardian Renata Manuardi ${ }^{2}$, Rini Meilani ${ }^{3}$ \\ ${ }^{123}$ Program Studi Bimbingan dan Konseling, Fakultas Ilmu Pendidikan, IKIP Siliwangi \\ sitifatimah432@ikipsiliwangi.ac.id ${ }^{1}$ \\ manuardirenata@ outlook.com ${ }^{2}$ \\ rinimeii07@gmail.com ${ }^{3}$
}

\begin{abstract}
Abstrak
Efikasi diri performa akademik adalah keyakinan atas kemampuan diri sendiri dalam melakukan segala aktivitas yang menunjang proses belajar individu. Perkembangan efikasi diri dalam tiap fase dibutuhkan kompetensi dari individu itu sendiri untuk berhasil melalui tiap fase tersebut, meskipun tahap perkembangan yang dilalui individu tidaklah sama. Hal ini dikarenakan permasalahan dalam pendidikan sangat kompleks, dimulai dengan perubahan struktur kurikulum yang selalu berubah setiap pergantian pemangku kepentingan juga permasalahan teknis lainnya yang berimbas langsung kepada proses-proses pendidikan yang sedang berlangsung. Penelitian ini bertujuan untuk mengetahui tingkat efikasi diri mahasiswa Bimbingan dan Konseling IKIP Siliwangi dari perspektif dimensi Bandura. Metode yang digunakan adalah deskriptif kuantitatif dengan menganalisis data yang diperoleh dari angket yang disebarkan secara daring. Hasil dari penelitiannya adalah 23,9\% mahasiswa berada pada kategori efikasi diri performa akademik rendah, disusul sebanyak 61,2\% mahasiswa yang termasuk ke dalam kategori efikasi diri performa akademik sedang, dan terakhir terdapat 14,9\% mahasiswa yang termasuk ke dalam kategori efikasi diri performa akademik tinggi. Kemudian, tingkat efikasi diri performa akademik ini lebih banyak dipengaruhi oleh tingkat kekuatan dan kemantapan individu terhadap keyakinannya serta kemampuan individu dalam menguasai suatu tugas.
\end{abstract}

Kata Kunci: Efikasi Diri; Performa Akademik; Mahasiswa; Dimensi Bandura.

\section{PENDAHULUAN}

Mahasiswa didefinisikan sebagai individu yang menuntut ilmu di tingkat perguruan tinggi yang pada umumnya berada pada tahapan remaja akhir, yakni rentang usia 18-25 tahun (Siswoyo dalam Faradillah \& Amriana, 2020). Mahasiswa juga merupakan komponen penting dalam dunia pendidikan khususnya dalam proses belajar mengajar yang memiliki peran sebagai subjek maupun objek pembelajaran, namun performa belajar mahasiswa ini tentunya tidak bisa dipisahkan dari bagaimana dirinya mengendalikan diri terkait kondisi 
psikologisnya yang meliputi keadaan mental individu yang sehat, sehingga mampu melakukan pengaturan terhadap perilakunya dengan efektif.

Menurut Bandura (Bart, 1994) untuk mengatur perilaku akan dibentuk atau tidak, individu tidak hanya mempertimbangkan informasi dan keyakinan tentang keuntungan dan kerugian, tetapi juga mempertimbangkan sampai sejauh mana individu mampu mengatur perilaku tersebut, yang dikenal dengan sebutan efikasi diri. Baron dan Byrne (Permana, Harahap, \& Astuti, 2016) menyatakan bahwa efikasi diri akademik berhubungan dengan keyakinan individu akan kemampuannya mengerjakan tugas, mengatur kegiatan belajarnya sendiri, dan hidup dengan harapan akademis dirinya dan orang lain.

Efikasi memegang peran yang sangat penting dalam kehidupan sehari-hari, seseorang akan mampu menggunakan potensi dirinya secara optimal apabila efikasi diri mendukungnya. Untuk itu, sangat penting bagi setiap individu untuk mampu menilai dirinya apakah memiliki kekuatan dalam menghasilkan sesuatu yang diinginkan, karena hal tersebut menunjukkan tingginya efikasi diri yang akan dipersepsikan sebagai motivasi bagi individu secara kognitif untuk bertindak secara tepat dan terarah, terutama apabila tujuan yang hendak dicapai merupakan tujuan yang jelas (Bandura dalam Ormrod, 2008). Efikasi diri selalu berhubungan dan berdampak pada pemilihan perilaku, motivasi dan keteguhan individu dalam menghadapi setiap persoalan. Meskipun masih banyak mahasiswa yang belum mampu mengetahui ataupun mengoptimalkan segala kemampuan, keterampilan dan kompetensi yang dimilikinya. Hal ini menyebabkan masih banyaknya mahasiswa yang memiliki efikasi diri rendah.

Terdapat tiga komponen yang memberikan dorongan bagi terbentuknya efikasi diri, yaitu sebagai berikut (Rachmahana, 2008).

1. Outcome Expectancy (Pengharapan Hasil)

Pengharapan hasil adalah harapan akan kemungkinan hasil dari perilaku. Ketika individu mengerjakan suatu tugas dengan keyakinan akan kemampuan yang dimiliki diri secara penuh, maka individu pula akan mengharapkan hasil yang maksimal. Harapan tersebut berdasarkan keyakinan adanya hubungan yang menjembatani kinerja tugas dengan hasil. Harapan ini berwujud perkiraan kognitif tentang kemungkinan hasil yang akan diperoleh dan kemungkinan tercapainya tujuan melalui keberhasilan kinerja tersebut akan berfungsi sebagai penguat dari usaha dan keyakinan yang dimiliki.

2. Efficacy-Expectancy (Pengharapan Efikasi)

Harapan efikasi yaitu harapan atas munculnya perilaku yang dipengaruhi oleh persepsi individu pada kemampuan kinerjanya yang berkaitan dengan hasil. Usaha yang dilakukan tentu memiliki harapan akan hasil yang memuaskan. Pengharapan efikasi cenderung digeneralisasikan pada situasi atau tugas lain yang sama dan berhubungan dengan situasi dan tugas sebelumnya. Bila seseorang sering mengalami kegagalan pada suatu tugas tertentu maka ia cenderung memiliki efikasi diri yang rendah pada tugas lain. Demikian pula apabila ia mendapatkan keberhasilan maka efikasi dirinya akan meningkat pada semua tugas yang memiliki kemiripan. Hal tersebut karena adanya perubahan terhadap keyakinan akan kemampuan yang dimilikinya. 


\section{Outcome Value (Nilai Hasil)}

Nilai hasil yaitu nilai kebermaknaan atas hasil yang diperoleh individu. Nilai hasil yang sangat berarti akan memberikan pengaruh secara kuat pada motivasi individu untuk mendapatkannya kembali, karena hasil merupakan kepuasan dari usaha yang dilakukan yang akan meningkatkan efikasi diri.

Bandura (1995) mendefinisikan efikasi diri sebagai keyakinan untuk menarik kesimpulan terhadap situasi yang sedang dihadapi. Efikasi diri berbeda dengan ekspektasi hasil respons. Efikasi diri yang dipersepsi mengacu pada keyakinan seseorang tentang kapabilitasnya untuk mengorganisasikan dan melaksanakan rangkaian tindakan yang dibutuhkan untuk mengelola situasi prospektif. Ekspektasi hasil adalah judgment tentang kemungkinan konsekuensi yang akan dihasilkan perilaku tersebut. Judgment bahwa seseorang mampu lulus dengan nilai sangat baik adalah sebuah judgment efikasi. Tetapi pengakuan sosial yang diantisipasi melalui lulus dengan nilai baik adalah ekspektasi hasil, dan hasil adalah konsekuensi tindakan dan bukan tindakan itu sendiri. Seseorang dengan efikasi diri, percaya bahwa dirinya dapat melakukan sesuatu untuk mengubah kejadiankejadian disekitarnya dengan berusaha lebih keras untuk mengatasi tantangan yang ada, sedangkan seseorang dengan efikasi diri rendah menganggap dirinya tidak mampu mengerjakan segala sesuatu yang ada disekitarnya dan cenderung mudah menyerah (Maryam, 2015).

Menurut sebuah analisis mengenai efikasi diri yang dilakukan oleh Gist dan Mitchel (dalam Tamimi, 2019) menyatakan bahwa efikasi diri berhubungan dengan kinerja pekerjaan, pilihan karir, pembelajaran dan pencapaian, dan kemampuan beradaptasi dengan teknologi baru. Hal tersebut sesuai dengan pendapatnya Saputra \& Widiasari (Fatimah, Suherman, \& Rohaeti, 2019) bahwa masih banyak peserta didik yang masih cenderung terpengaruh oleh keputusan karir yang dilakukan orang lain, tidak percaya diri, kurangnya pengetahuan tentang pekerjaan yang dinginkan, terpaku pada satu pilihan, tidak mampu mengenali minat dan bakatnya, merasa tidak mendapat dukungan dari orang lain, tidak pasti dalam membuat pilihan, dan mengalami masalah berkenaan dengan pekerjaan yang diharapkan. Suatu studi penelitian yang berskala besar menemukan bahwa individu yang memiliki efikasi diri tinggi cenderung berkinerja pada suatu tingkatan yang lebih tinggi. Mendukung kesimpulan ini adalah penelitian Bandura dan Locke (dalam Tamimi, 2019) yang menemukan bahwa ketika dikombinasikan dengan penetapan tujuan, individu dengan efikasi diri yang tinggi cenderung menunjukkan tingkat motivasi dan kinerja yang lebih tinggi, karena salah satu aspek kehidupan yang dipengaruhi oleh efikasi diri adalah prestasi.

Secara etimologi, prestasi atau dengan kata lain performa dapat diartikan sebagai performa yang berarti tindakan dalam melaksanakan rangkaian tugas sebagai misi atau dalam bahasa Inggris disebut sebagai performance yang didefinisikan oleh Bernardin \& Russell (1993) bahwa "performance is defined as the record ofoutcomes produced on a specified job function or activity during a specified time period". Dapat diartikan bahwa performa adalah hasil dari suatu kegiatan selama suatu periode waktu tertentu. Manuardi (2018) 
mendefinisikan efikasi diri performa akademik sebagai keyakinan pada diri individu untuk mengarahkan dirinya melalui kemampuan mengontrol proses berfikir, motivasi, dan tindakannya yang bertujuan untuk menguasai situasi tertentu yang mengarah pada ilmu pengetahuan yang bersifat ilmiah dan telah diuji kebenarannya, sehingga bisa diukur baik berupa nilai maupun yang biasanya disebut dengan prestasi akademik.

Adapun ciri-ciri efikasi diri performa akademik dapat dilihat melalui tiga dimensi (Bandura dalam Jones, 2011) yaitu: 1) magnitude atau tingkat kesulitan tugas yang dihadapi individu; 2) generality atau kemampuan individu dalam menguasai suatu tugas; dan 3) strength atau kekuatan dan kemantapan individu terhadap keyakinannya. Adapun secara terperincinya adalah sebagai berikut.

\section{a. Magnitude}

Dimensi ini berkaitan dengan derajat kesulitan tugas yang ditujukan kepada individu. Apabila tugas-tugas yang dibebankan pada individu disusun 3 menurut tingkat kesulitannya, maka perbedaan efikasi diri secara individual mungkin terbatas pada tugas-tugas yang tergolong sederhana, menengah atau berat.

\section{b. Generality}

Dimensi ini berkaitan dengan penguasaan individu terhadap bidang atau tugas pekerjaan. Individu dapat menyatakan dirinya memiliki efikasi diri pada aktivitas yang luas, atau terbatas pada fungsi domain tertentu saja.

c. Strength

Dimensi yang ketiga ini lebih menekankan pada tingkat kekuatan atau kemantapan individu terhadap keyakinannya. Efikasi diri menunjukkan bahwa tindakan yang dilakukan individu akan memberikan hasil yang sesuai dengan yang diharapkan individu.

Dalam aspek kognitif, efikasi diri performa akademik memengaruhi individu dalam memandang kemampuan dirinya, terutama dalam penyelesaian tugas-tugas yang sulit. Individu yang memiliki keyakinan terhadap kemampuannya dalam menyelesaikan tugastugas akademik tidak akan menghindar dari tugas-tugas yang sulit, dan merasa percaya diri mampu menyelesaikan tugas-tugas tersebut meskipun sifatnya cenderung sulit (Makaria, Rachman, \& Rachmayanie, 2019). Aspek afektif, individu yang memiliki keyakinan akademik dan kepercayaan diri tinggi, akan berusaha keras, gigih, dan ulet, serta sangat yakin dapat menyelesaikan tugas-tugas akademik yang sulit (Makaria, Rachman, \& Rachmayanie, 2019). Aspek perilaku, efikasi diri akademik dan kepercayaan diri yang tinggi akan membuat individu tetap menampilkan kemampuan terbaiknya dalam berbagai situasi dan kegiatan akademik.

Teori sosial kognitif berpendapat bahwa efikasi diri akademik yang rendah dapat menyebabkan rasa cemas dan perilaku menghindar dari aktivitas-aktivitas yang cenderung sulit atau berat untuk diselesaikan oleh individu tersebut, terutama dalam hal akademik (Bandura dalam Hakim, 2021). Hal ini akan menunjukkan bagaimana individu tersebut memandang diri sendiri, merasa terhadap diri sendiri, dan tingkah laku yang mewujudkan 
diri sendiri dalam kehidupan sehari-hari. Efikasi diri akademik yang rendah akan menunjukkan kepercayaan diri yang rendah, terutama dalam bidang akademik. Individu dengan keyakinan diri terhadap kemampuan akademik yang rendah, akan membuat pandangan, perasaan, dan menunjukkan tingkah laku akademik yang tidak percaya diri. Efikasi diri akademik yang tinggi akan menunjukkan pikiran, perasaan dan perilaku akademik yang yakin, ulet dan gigih dalam menyelesaikan tugas-tugas akademik yang sulit sekalipun.

Setiap individu akan berusaha menyelesaikan tugas yang dibebankan padanya dan menyesuaikan tugas yang berat atau ringan sesuai dengan kemampuan yang dimilikinya. Hal ini dapat dilihat dari motivasi seseorang yang tidak maksimal yang dipengaruhi oleh efikasi diri apabila di dalam diri individu tersebut tidak memiliki efikasi diri yang tinggi dan kepercayaan diri baik di lingkungan sekolah maupun kehidupan sehari-harinya (Damayanti, 2017). Berdasarkan ciri-ciri tersebut, maka dapat disimpulkan bahwa inti dari efikasi diri performa akademik adalah keyakinan atas kemampuan diri sendiri dalam melakukan segala aktivitas yang menunjang proses belajar individu. Perkembangan efikasi diri dalam tiap fase dibutuhkan kompetensi dari individu untuk berhasil melalui tiap fase tersebut, meskipun tahap perkembangan yang dilalui setiap individu tidaklah sama. Efikasi diri yang tinggi membuat mahasiswa menjadi semakin percaya akan kemampuan dirinya dan mampu menemukan solusi ketika menghadapi masalah dalam menyelesaikan kewajiban sebagai mahasiswa. Masalah yang muncul membuat keyakinan mahasiswa menjadi semakin tinggi, sehingga mahasiswa mampu menyelesaikan tugasnya dengan baik dan tepat waktu.

\section{METODE PENELITIAN}

Pendekatan dalam penelitian ini menggunakan pendekatan kuantitatif, yaitu cara penanggulangan persoalan yang terprogram dan telaten melalui rancangan yang terkonstruksi selektif, pengumpulan data sebagai analitis terdominasi serta terarah atas kategorisasi ide yang disimpulkan sebagai induktif dan konteks justifikasi hipotesis secara empiris (Tanzeh dalam Nursa, 2021). Adapun jenis penelitiannya adalah deskriptif yaitu suatu penelitian atau pengkajian yang berupaya menggambarkann suatu indikasi, perkara, kasus yang berlaku pada era sekarang (Arikunto, 2010). Dengan demikian telaah deskriptif kuantitatif adalah metode penelitian yang digunakan untuk meneliti populasi atau sampel tertentu, analisis data bersifat kuantitatif dengan tujuan untuk menguji hipotesis yang telah ditetapkan sesuai dengan kejadian yang terjadi saat sekarang.

Alat ukur yang digunakan dalam pengumpulan data penelitian ini adalah angket skala efikasi diri performa akademik yang diturunkan dari pespektif dimensi Bandura (Manuardi, 2018) yang terdiri dari aspek keyakinan mahasiswa akan kemampuannya menyelesaikan tugas akademik (magnitude), ketangguhan mahasiswa untuk menyelesaikan tugas dalam berbagai tingkat kesulitan tugas akademik (strength), dan keberhasilan mahasiswa dalam mengerjakan suatu tugas akademik, sehingga mempengaruhi keyakinannya dalam menyelesaikan tugas lainnya (generality). Alat ukur ini mempunyai empat pilihan jawaban dengan skor tiap butir berkisar antara 1 sampai 4 dengan pilihan jawaban: Sangat Sesuai 
(SS), Sesuai (S), Tidak Sesuai (TS), dan Sangat Tidak Sesuai (STS). Instrumen ini berfungsi sebagai alat ukur untuk mengungkap suatu trait atau konstruk teoritis yang hendak diukur (Azwar, 2010).

Tahap pengumpulan data yang digunakan dalam penelitian ini adalah dengan pemberian kuesioner atau angket secara daring (menggunakan Google Formulir) kepada mahasiswa Bimbingan dan Konseling IKIP Siliwangi yang menjadi sasaran penelitian sebanyak 223 mahasiswa kemudian dianalisis setiap butir soalnya. Analisis data adalah proses mencari dan menyusun secara sistematis data yang diperoleh dengan mengorganisasikan data ke dalam kategori, menjabarkan ke dalam unit-unit, melakukan sintesa, menyusun ke dalam pola, memilih mana yang penting dan akan dipelajari, dan membuat kesimpulan sehingga mudah dipahami oleh diri sendiri maupun orang lain (Sugiyono, 2010).

\section{HASIL DAN PEMBAHASAN (Times New Roman 11, Bold, Spasi 1.15)}

Hasil penelitian ini diperoleh melalui penyebaran instrumen efikasi diri performa akademik yang bertujuan untuk memperoleh gambaran tingkat efikasi diri performa akademik yang dimiliki oleh mahasiswa Bimbingan dan Konseling IKIP Siliwangi selama pembelajaran online terkait tingkat kesulitan tugas yang dihadapi individu, kemampuan individu dalam menguasai suatu tugas, dan kemantapan individu terhadap keyakinannya. Adapun hasilnya adalah sebagai berikut:

Tabel 1. Klasifikasi Tingkat Efikasi Diri Performa Akademik

\begin{tabular}{c|c|c}
\hline Kriteria & Kategori & Persentase \\
\hline $\mathbf{X}>\mathbf{7 6}$ & Tinggi & $\mathbf{1 4 , 9 \%}$ \\
\hline $\mathbf{6 1}-\mathbf{6 8}$ & Sedang & $\mathbf{6 1 , 2 \%}$ \\
\hline $\mathbf{X}<\mathbf{6 0}$ & Rendah & $\mathbf{2 3 , 9 \%}$ \\
\hline Jumlah & & $\mathbf{1 0 0 \%}$ \\
\hline
\end{tabular}

Berdasarkan tabel di atas, dapat diketahui bahwa profil/gambaran efikasi diri performa akademik mahasiswa Bimbingan dan Konseling IKIP Siliwangi secara umum berada pada kategori sedang yaitu sebesar 61,2\% dengan aspek efikasi diri performa akademik yang lebih banyak dipengaruhi oleh tingkat kekuatan dan kemantapan individu terhadap keyakinannya serta kemampuan individu dalam menguasai suatu tugas. Adapun urutan indikator efikasi diri performa akademik yang lebih dominan adalah yang berkaitan dengan memiliki ekspektasi tinggi terhadap tugas-tugas akademik, berorientasi terhadap masa depan, meyakini kemampuannya sebagai modal meraih keberhasilan di masa mendatang, dan memiliki gairah (passion) dalam belajar.

Sama seperti yang dihasilkan dalam penelitian ini, Prianto (2007) melakukan penelitian pada mahasiswa Fakultas Psikologi Universitas Sanata Dharma Yogyakarta tahun akademik 2002, 2003, 2004, 2005, dan 2006 dengan jumlah subjek penelitian 116 orang. Secara umum, berada pada kategori sedang sehingga masih ada mahasiswa yang dianggap 
kurang mampu mendapatkan informasi tentang dirinya yang positif, namun, ada pula sebagian yang sudah mampu mendapatkan informasi yang positif dari dirinya.

Berbeda dengan penelitian yang dilakukan oleh Liwu (2014) pada mahasiswa Program Studi Bimbingan dan Konseling Universitas Sanata Dharma Yogyakarta angkatan 2010 dengan jumlah subjek penelitian 40 orang, menunjukkan bahwa efikasi diri mahasiswa dalam mengerjakan skripsi rata-rata berada dalam kategorisasi tinggi yaitu $70 \%$ mahasiswa. Sebagian besar mahasiswa sudah memiliki motivasi yang tinggi serta pikiran akan keyakinan hasil yang baik sejalan dengan usaha yang telah dilakukan, dan sudah mampu menyelesaikan skripsi sesuai dengan target yang ditentukan, sehingga mencapai keberhasilan yang diharapkan.

Efikasi diri merupakan hal yang penting dan harus dimiliki oleh mahasiswa karena efikasi diri dapat mempengaruhi proses berfikir, level motivasi belajar, dan kondisi perasaan yang semuanya berperan terhadap jenis performasi yang dilakukan (Simaremare, 2018). Individu dengan efikasi diri rendah dalam mengerjakan tugas tertentu akan cenderung menghindari tugas tertentu, individu tidak memiliki keyakinan terhadap dirinya untuk menyelesaikan tugas. Individu akan merasa sulit untuk memotivasi diri akan mengurangi usahanya atau menyerah pada permulaan rintangan. Individu juga mempunyai aspirasi dan komitmen lemah untuk tujuan hidup yang akan dipilih.

Menurut (Bandura dalam Simaremare, 2018) efikasi diri juga mempengaruhi besar usaha dan ketahanan individu dalam menghadapi kesulitan. Individu dengan efikasi diri tinggi memandang tugas-tugas sulit sebagai tantangan untuk dihadapi dari pada sebagai ancaman untuk dihindari. Mahasiswa yang memiliki efikasi diri yang tinggi akan selalu siap menghadapi setiap persoalan yang dihadapi ketika menyelesaikan tugas. Mahasiswa mempunyai komitmen tinggi untuk mencapai tujuan-tujuannya, mahasiswa juga akan menginvestasikan tingkat usaha yang tinggi dan berfikir strategis untuk menghadapi kegagalan. Individu memandang kegagalan sebagai kurangnya usaha untuk mencapai keberhasilan. Selain itu, individu secara cepat memulihkan perasaan mampu setelah mengalami kegagalan.

Maddox (Simaremare, 2018) menguraikan bahwa seseorang yang mempunyai efikasi diri tinggi akan mempunyai kemampuan untuk menyesuaikan diri lebih baik, dapat mempengaruhi situasi, dan dapat menunjukkan kemampuan yang dimiliki dengan lebih baik, sehingga dapat menghindarkan diri dari reaksi psikis. Kemampuan berpikir juga diperlukan dalam mengembangkan efikasi diri (Rustika, 2012), karena orang yang memiliki kemampuan berpikir atau intelegensi yang tinggi memiliki kemampuan menganalisa kejadian-kejadian yang pernah dialami. Hampir semua penyebab dari tingkah laku berawal dari pikiran dan keyakinan seseorang mengenai efikasi diri memberikan peranan pada proses berpikir mereka dalam menentukan goal setting dan membuat perencanaan ketika menghadapi suatu tugas. Keyakinan tersebut mempengaruhi tipe dari skenario antisipasi dan berlatih menggunakannya dalam pikiran. Sebagai contoh Bandura (1997) mengatakan bahwa seseorang yang mempunyai efikasi diri yang tinggi akan melihat skenario keberhasilan yang dapat membangun arahan dan dukungan yang positif. Seseorang yang meragukan keyakinan 
yang dimiliki akan melihat skenario kegagalan dan memikirkan banyak kemungkinan hal yang dapat berjalan tidak benar.

Perubahan yang terjadi pada setiap individu dipengaruhi oleh berbagai faktor baik internal atau eksternal (Simaremare, 2018). Faktor internal ialah stimulus yang berasal dari dalam diri individu itu sendiri, seperti keyakinan akan kemampuan diri untuk menghasilkan suatu performa tertentu. Adapun yang dimaksud dengan faktor eksternal ialah stimulus yang datang dari luar individu, seperti lingkungan tempat tinggal, fasilitas, model dan sebagainya. Manajemen yang baik dari kedua faktor tersebut dapat menghasilkan performa akademik yang diinginkan peserta didik atau mahasiswa. Adanya performa akademik yang maksimal menunjukkan berhasilnya pembelajaran, karena adanya perubahan ke arah yang positif.

Menurut Bandura (1997) yang dapat membentuk efikasi diri diantaranya adalah pengalaman berhasil, pengalaman melalui pengamatan, persuasi verbal dan emosi yang tampak. Keberhasilan merupakan hal yang dapat meningkatkan efikasi diri seseorang, karena dengan keberhasilan, seseorang akan lebih yakin terhadap kemampuan yang ada pada dirinya, sebaliknya pengalaman kegagalan akan menyebabkan efikasi diri seseorang menjadi rendah, karena merasa tidak memiliki kemampuan dalam mencapai sesuatu. Selain pengalaman berhasil, pada waktu seseorang merasa sedih, maka penilaian terhadap diri cenderung rendah serta merasa bahwa dirinya tidak berarti. Orang cenderung membuat evaluasi diri positif pada waktu suasana hati positif, dan evaluasi negatif pada waktu suasana hati negatif. Efikasi diri tinggi akan diraih ketika seseorang mengalami keberhasilan dan pada saat suasana hati positif, sedangkan efikasi diri akan rendah ketika seseorang mengalami kegagalan dan pada waktu suasana hati negatif. (Rustika, 2012).

Prestasi atau performa akademik (Setiawan dalam Wahyuni \& Dahlia, 2020) adalah hal yang menunjukkan pencapaian tingkat keberhasilan suatu tujuan karena usaha belajar yang telah dilakukan oleh seseorang secara optimal. Prestasi akademik berfokus pada nilai atau angka yang dicapai individu dalam proses pembelajaran di sekolah atau perguruan tinggi. Adanya pengalaman keberhasilan yang diperoleh individu di masa lalu dapat memberikan peluang untuk menaikkan efikasi diri akademiknya, sedangkan pengalaman kegagalan pada individu di masa lalu dapat menurunkan efikasi diri akademik. Minimnya pengalaman kegagalan pada seseorang diasumsikan memiliki kontribusi pada efikasi diri akademik yang cenderung tinggi $(41,24 \%)$ (Wahyuni \& Dahlia, 2020).

Efikasi diri performa akademik jika disertai dengan tujuan-tujuan yang spesifik dan pemahaman mengenai prestasi akademik, maka akan menjadi penentu suksesnya akademik (Bandura, dalam Alwisol, 2004). Pemahaman ini menggambarkan bahwa efikasi diri akademik dapat menjadi suatu sumber daya yang sangat penting bagi pengembangan diri melalui pilihan aktivitas mahasiswa (Schunk, 2012.). Efikasi diri akademik berhubungan dengan cara berpikir individu dalam menghadapi masalah dan arah berpikir individu dalam memandang masalah secara optimis atau pesimis, karena akan menentukan cara menghadapi kesulitan-kesulitan akademik, serta individu dengan efikasi yang tinggi akan bertahan dalam menghadapi kesulitan. Salah satu upaya meningkatkan efikasi diri akademik adalah melalui penambahan kemampuan seseorang untuk memodifikasi keyakinan-keyakinannya dengan 
melatih kemampuan berpikirnya, hal ini karena cara dan pola berpikir seseorang mempengaruhi perilaku dan perasaan yang akan dimunculkan dalam suatu situasi (Ellis dalam Corey, 2007).

\section{SIMPULAN}

Simpulan dari penelitian ini adalah didapatkannya profil/gambaran efikasi diri performa akademik mahasiswa Bimbingan dan Konseling IKIP Siliwangi yang secara umum berada pada kategori sedang yaitu sebesar 61,2\% dengan aspek efikasi diri performa akademik yang lebih banyak dipengaruhi oleh tingkat kekuatan dan kemantapan individu terhadap keyakinannya serta kemampuan individu dalam menguasai suatu tugas. Adapun urutan indikator efikasi diri performa akademik yang lebih dominan adalah yang berkaitan dengan memiliki ekspektasi tinggi terhadap tugas-tugas akademik, berorientasi terhadap masa depan, meyakini kemampuannya sebagai modal meraih keberhasilan di masa mendatang, dan memiliki gairah dalam belajar. Efikasi diri merupakan hal yang dapat mempengaruhi performa akademik, diantaranya karena memiliki kemampuan dalam berfikir atau intelektual yang tinggi, pengalaman yang membanggakan, keadaan mahasiswa yang positif, dan perasaan yang bahagia. Sementara itu, rendahnya efikasi diri dapat menyebabkan individu kesulitan dalam mencapai keberhasilan dalam pembelajaran.

\section{DAFTAR PUSTAKA}

Alwisol. (2004). Psikologi Kepribadian. Malang: UMM.

Arikunto, S. (2010). Prosedur Penelitian. Jakarta: PT. Rineka Cipta.

Azwar, S. (2010). Penyusunan Skala Psikologi. Yogyakarta: Pustaka Pelajar.

Bachria, R. D. (2012). Efikasi Diri Pada Performa Akademik Asisten Dosen Fakultas Psikologi Universitas Muhammadiyah Surakarta (Doctoral dissertation, Universitas Muhammadiyah Surakarta).

Bandura, A. (1995). Self-Efficacy in Changing Societies. New York: Cambridge University Press.

Bandura, A. (1997). Self Efficacy The Exercise of Control. New York: W. H. Freeman And Company.

Bart, S. (1994). Psikologi Kesehatan. Jakarta: PT. Gramedia Widiasarna Indonesia.

Bernardin, H. J \& Russel, J. E. A. (1993). Human Resource Management. Singapore: McGraw Hill, inc.

Corey, G. (2007). Teori dan Praktek Konseling dan Psikoterapi. Bandung: RefikaAditama.

Damayanti, D. (2017). Kontribusi Self Efficacy Terhadap Motivasi Berprestasi Peserta Didik Kelas V Sdn Gugus 1 Kecamatan Sandubaya Kota Mataram Tahun Pelajaran 2016/2017. S1 Thesis, Universitas Mataram. 
34 | Fatimah, Manuardi \& Meilani - Tingkat Efikasi Diri ...

Faradillah, S. S., \& Amriana, A. (2020). Cognitive-Behavioral Therapy dengan Teknik Thought Stopping untuk Menangani Trauma Psikologis Mahasiswa yang Mengalami Broken Home. Prophetic: Professional, Empathy and Islamic Counseling Journal, 3(1), hlm. 83-94.

Fatimah, S., Suherman, M. M., \& Rohaeti, E. E. (2019). Pelatihan Penerapan Metode Plans Untuk Mengembangkan Efikasi Diri Dalam Pengambilan Keputusan Karier Siswa Di Kabupaten Purwakarta. Jurnal Bimbingan dan Konseling Islam, 9(2), hlm. 121-130.

Hakim, L. (2021). Penguatan Efikasi Diri Pada Pribadi Introvert. Jurnal Konseling Pendidikan Islam, 2(1), hlm. 203-216.

Jones, R. N. (2011). Teori dan Praktik Konseling dan Terapi (Eds 4). Yogyakarta: Pustaka Pelajar.

Liwu, Y. F.D. (2014). Self Efficacy Mahasiswa Dalam Mengerjakan Skripsi Dan Implikasinya Terhadap Upaya Peningkatan Self Efficacy. Skripsi. Yogyakarta: Universitas Sanata Dharma Yogyakarta.

Madihah, M. (2019). Bibliokonseling Sebagai Upaya Meningkatkan Efikasi Diri Akademik Seorang Siswi Di MTs Miftahul Ulum Baturetno Singosari Malang (Doctoral dissertation, Universitas Islam Negeri Sunan Ampel).

Makaria, E. C., Rachman, A., \& Rachmayanie, R. (2019). Korelasi Kepercayaan Diri dan Efikasi Diri Akademik Mahasiswa Program Studi Bimbingan Dan Konseling Angkatan 2018. JKI (Jurnal Konseling Indonesia), 5(1), hlm. 1-5.

Manuardi, A. R. (2018). Pengaruh Strategi Restrukturisasi Kognitif terhadap Efikasi Diri Performansi Akademik Mahasiswa Psikologi Universitas Negeri Malang. http://mulok.library.um.ac.id/index3.php/89082.html.

Maryam, S. (2015). Self efficacy anak didik pemasyarakatan di Lapas anak kelas IIA Blitar (Doctoral dissertation, Universitas Islam Negeri Maulana Malik Ibrahim).

Nursa, R. A. (2021). Analisis Persepsi Peserta Didik Terhadap Bimbingan Dan Konseling Di SMAN 1 Tapan. Journal of Islamic Education and Innovation, 2(1), hlm. 70-78.

Ormrod, J.E. (2008). Psikologi Pendidikan. Jakarta: Erlangga

Permana, H., Harahap, F., \& Astuti, B. (2016). Hubungan Antara Efikasi Diri Dengan Kecemasan Dalam Menghadapi Ujian Pada Siswa Kelas IX di MTs Al Hikmah Brebes. Hisbah: Jurnal Bimbingan Konseling dan Dakwah Islam, 13(2), hlm. 51-68.

Prianto, F. X. R. (2010). Efikasi Diri Pada Mahasiswa Psikologi Universitas Sanata Dharma Yang Sedang Mengerjakan Skripsi. Skripsi (tidak diterbitkan). Yogyakarta: Fakultas Psikologi Universitas Sanata Dharma.

Rachmahana, R. S. A. (2008). Peran Efikasi Diri Terhadap Prestasi Dan Performansi: Meta Analisis. Psikologika: Jurnal Pemikiran dan Penelitian Psikologi, 13(25), hlm. 15-24.

Rustika, I. M. (2012). Efikasi Diri: Tinjauan Teori Albert Bandura. Buletin Psikologi, 20(12), hlm. 18-25. 
Simaremare, C. O. (2018). Efikasi Diri Mahasiswa Dalam Menyelesaikan Studinya (Studi Kasus Pada Mahasiswa Pendidikan Ekonomi). Jurnal efikasi diri mahasiswa dalam menyelesaikan studinya (Studi Kasus Pada Mahasiswa Pendidikan Ekonomi).

Schunk, Dale. H. (2012). Learning Theories: An Educational Perspectives, 6th Edition. New York: Pearson Education Inc.

Sugiyono. (2010). Metode Penelitian Kuantitatif, Kualitatif, dan R \&D. Bandung: Alfabeta.

Tamimi, I. (2019). Pengaruh Self Efficacy, Disiplin Kerja, Dan Lingkungan Kerja Terhadap Kinerja Karyawan Bagian Produksi Pada UD Roti Matahari Pasuruan.

Wahyuni, S. F., \& Dahlia, D. (2020). Hubungan Antara Efikasi Diri Akademik Dengan Prestasi Akademik Pada Siswa Sma Di Banda Aceh. Seurune Jurnal Psikologi Unsyiah, 3(2), hlm. 80-100. 
36 | Fatimah, Manuardi \& Meilani - Tingkat Efikasi Diri ... 